\title{
Red blood cell distribution width is not correlated with preeclampsia among pregnant Sudanese women
}

\author{
Hala Abdullahi ${ }^{1}$, Ameer Osman ${ }^{1}$, Duria A Rayis ${ }^{1}$, Gasim I Gasim² ${ }^{2}$ Abdulmutalab M Imam ${ }^{1}$ and Ishag Adam ${ }^{1,2^{*}}$
}

\begin{abstract}
Background: Preeclampsia is a leading cause of maternal and perinatal mortality worldwide. The exact etiology of preeclampsia is unknown, but the inflammatory process is postulated as one of the etiologies. Red blood cell distribution width (RDW) is a measure of anisocytosis (variation of red cell size) and is associated with hypertension and diabetic ketoacidosis. There are few data on the association between RDW and preeclampsia. This study aimed to investigate the association between RDW and preeclampsia.
\end{abstract}

Methods: A case-control study was conducted at Khartoum Hospital, Sudan, during June to August 2012. Cases were women with preeclampsia and healthy women were controls. Sociodemographic characteristics, obstetrics, and clinical data were recorded. The complete blood count, including RDW, was measured using an automated hematology analyzer.

Results: The cases and controls (65 women in each arm) were matched in their basic characteristics. There was no difference in the mean (SD) RDW between women with preeclampsia and controls ( $14.5 \pm 1.8 \%$ vs. $14.4 \pm 1.4 \%$, $\mathrm{P}=0.710$ ). There was also no difference in the mean RDW between women with mild and severe preeclampsia $(14.7 \pm 1.9 \%$ vs. $13.9 \pm 1.4 \%, P=0.144$. In logistic regression, there was no association between RDW and preeclampsia ( $\mathrm{OR}=0.9, \mathrm{Cl}=0.7-1.1, \mathrm{P}=0.952)$.

Conclusions: RDW levels are not associated with the presence or severity of preeclampsia.

Virtual slides: The virtual slide(s) for this article can be found here: http://www.diagnosticpathology.diagnomx.eu/ vs/1206247718115175

Keywords: Preeclampsia, Red cell distribution width, Pregnancy Sudan

\section{Background}

Preeclampsia is a leading cause of maternal and perinatal mortality worldwide [1]. The exact underlying pathology for the development of preeclampsia is not yet completely understood. Placental pathology causing preeclampsia has been suggested, with inadequate cytotrophoblast invasion and widespread maternal endothelial dysfunction [2]. Increased erythropoietic stimulation associated with underlying placental hypoxia has been observed in preeclampsia [3].

\footnotetext{
* Correspondence: ishagadam@hotmail.com

${ }^{1}$ Department of Obstetrics and Gynecology, Faculty of Medicine, University

of Khartoum, Khartoum, Sudan

${ }^{2}$ College of Medicine, Qassim University, Qassim, Saudi Arabia
}

Red cell distribution width (RDW) is a parameter, which is usually evaluated in a fully automated hematology analyzer, as part of the complete blood count. RDW is a marker of anisocytosis (red cell size variation). RDW can reflect early changes in red blood cells, and these are accompanied by iron deficiency anemia, and have been shown to have a high sensitivity at detecting anemia $[4,5]$.

Recent research has shown that RDW is higher in prehypertension and hypertension in the non-pregnant population [6]. Furthermore, highly significant associations have been described between RDW values and diabetic ketoacidosis, cardiovascular and thrombotic disorders, and cardiac mortality in patients with coronary artery disease, acute and chronic heart failure, and stroke $[7,8]$. However, the vast majority of the data on RDW 
Table 1 The mean (SD) of the characteristics of women with preeclampsia and controls

\begin{tabular}{llll}
\hline Variables & $\begin{array}{l}\text { Women with } \\
\text { preeclampsia } \\
(\mathbf{n}=65)\end{array}$ & Controls & $\mathbf{P}$ \\
\hline Age, years & $29.6(5.4)$ & $29.1(4.6)$ & 0.604 \\
Parity & $2.8(1.8)$ & $2.7(1.9)$ & 0.882 \\
Body mass index kg/ ${ }^{2} \mathrm{Cm}$ & $23.8(2.1)$ & $24.2(1.8)$ & 0.245 \\
Hemoglobin, $\mathrm{g} / \mathrm{dl}$ & $11.4(1.4)$ & $11.7(1.2)$ & 0.192 \\
Platelets $\times 10^{3} \mathrm{\mu L}$ & $220153(8477)$ & $221752(6899)$ & 0.906 \\
White blood cell $\times 10^{3} \mathrm{\mu L}$ & $7489(3308)$ & $8000(2204)$ & 0.906 \\
\hline
\end{tabular}

and hypertension are on the non-pregnant population, with few data on RDW and preeclampsia [9].

Therefore, the current study was conducted to investigate the association between RDW and preeclampsia at Khartoum Hospital, Sudan. This study aimed to add to the knowledge on pathogenesis on preeclampsia [10-13] and examine the diagnostic value of RDW in various diseases in this setting (Sudan) [14]. In Sudan, there is an extremely high maternal mortality, with preeclampsia/ eclampsia accounting for $4.2 \%$ of obstetric complications and $18.1 \%$ of maternal deaths $[15,16]$.

\section{Methods}

A case-control study was carried out at Khartoum Hospital, Sudan, during June to August 2012. Khartoum Hospital is a tertiary hospital serving the local community and receiving medical referrals from other parts of Sudan. After signing an informed consent, women carrying a singleton pregnancy were enrolled. A case was defined
Table 2 The mean (SD) of the of characteristics of women with mild and severe preeclampsia

\begin{tabular}{llll}
\hline Variables & $\begin{array}{l}\text { Women with mild } \\
\text { preeclampsia } \\
(\mathbf{n}=\mathbf{1 5})\end{array}$ & $\begin{array}{l}\text { Women with severe } \\
\text { preeclampsia } \\
(\mathbf{n}=\mathbf{5 0})\end{array}$ & $\mathbf{P}$ \\
\hline Age, years & $29.8(5.1)$ & $28.9(5.2)$ & 0.563 \\
Parity & $2.7(1.5)$ & $3.3(2.4)$ & 0.238 \\
$\begin{array}{l}\text { Body mass } \\
\text { index kg/ }{ }^{2} \mathrm{~cm}\end{array}$ & $23.6(2.6)$ & $24.4(1.8)$ & 0.195 \\
Hemoglobin, g/dl & $10.4(1.3)$ & $10.7(1.5)$ & 0.760 \\
Platelets $\times 10^{3} \mu \mathrm{L}$ & $243760(8141)$ & $141466(31999)$ & $<0.001$ \\
$\begin{array}{l}\text { White blood } \\
\text { cell } \times 10^{3} \mu \mathrm{L}\end{array}$ & $7388(4089)$ & $7826(4089)$ & 0.657 \\
\hline
\end{tabular}

as a woman with preeclampsia who was diagnosed according to the criteria of the international society for the study of hypertension in pregnancy [17]: a diastolic blood pressure of $\geq 90 \mathrm{mmHg}$ measured 4 hours apart, plus proteinuria of more than $1+$ by dipsticks or a 24hour urine level $\geq 300 \mathrm{mg}$. Cases were further divided into mild and severe preeclampsia according to diastolic blood pressure $<110$ or $\geq 110 \mathrm{mmHg}$. Pregnant women with multiple pregnancies or medical disorders, such as diabetes mellitus or inflammatory conditions, were excluded. The control group included healthy pregnant women with no known medical or obstetric complications. A pre-tested questionnaire was used to gather data from each woman in cases and control groups. The women's age, parity, and gestational age were recorded. Weight and height were measured, and body mass index (BMI) was calculated as weight in kilograms divided by the square of height in meters. The

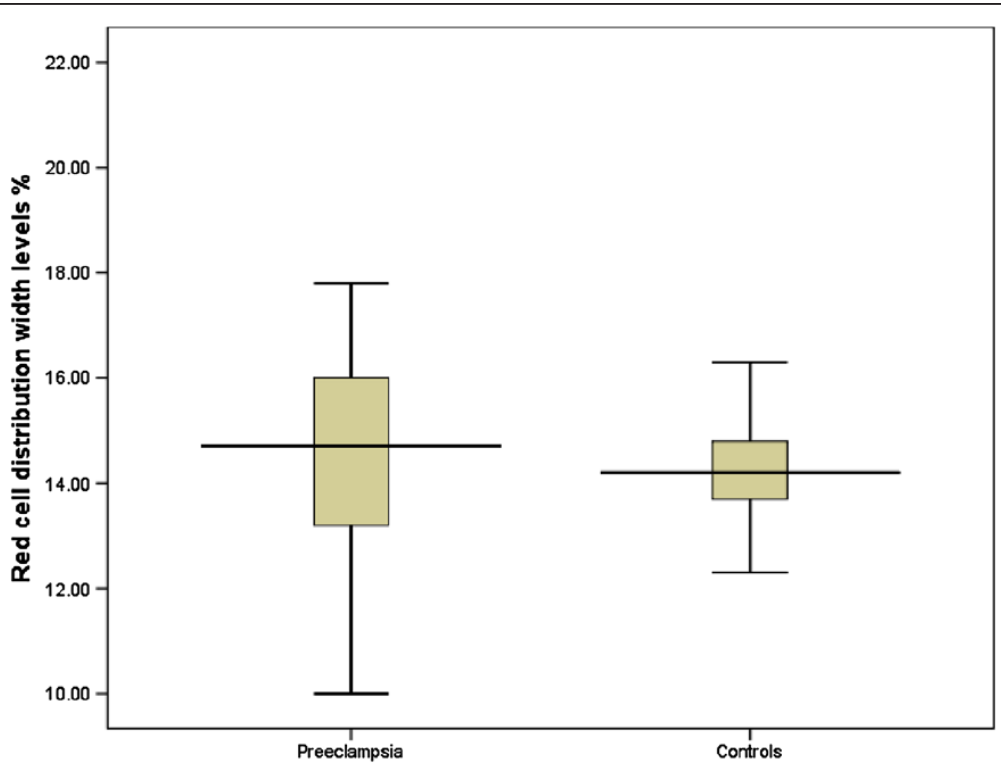

Figure 1 Comparison of red cell distribution width levels in the preeclampsia and control groups. 


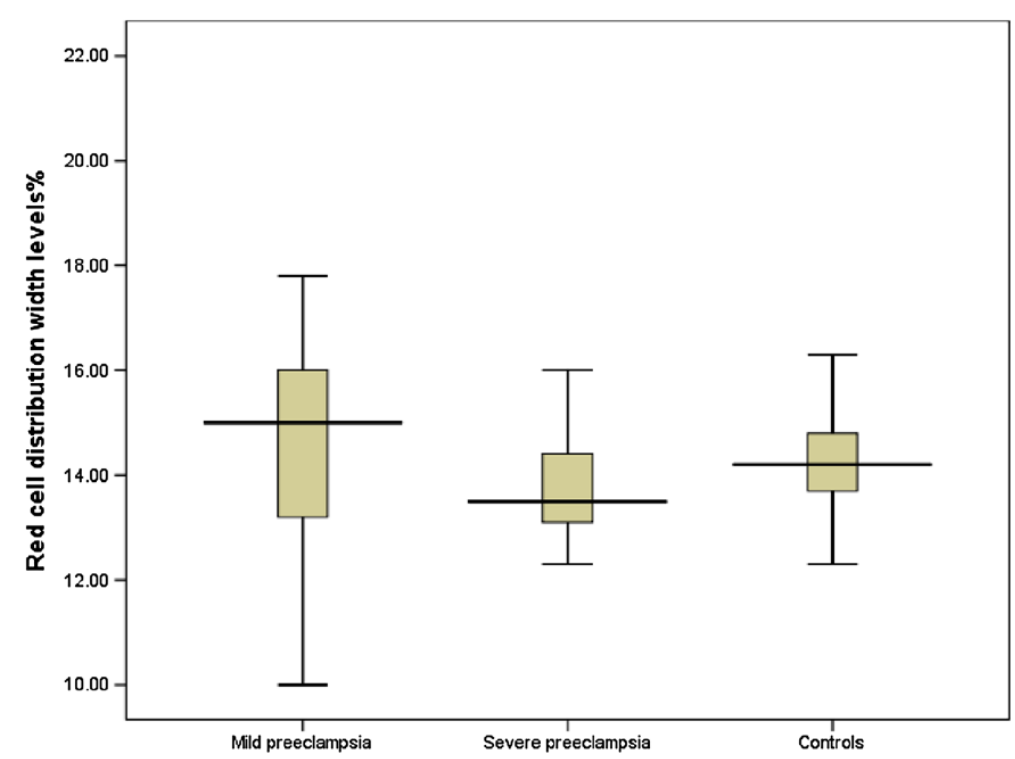

Figure 2 Comparison of red cell distribution width levels in the preeclampsia and control groups.

maternal complete blood count was measured for all women using an automated hematology analyzer as previously described $[14,18,19]$.

A sample size of 65 subjects in each arm of the study was calculated using the OpenEpi-Epidemiological calculator with $80 \%$ power and a confidence interval of $95 \%$ to detect a difference of $5 \%$ at $\alpha=0.05$, with $10 \%$ of non-respondents/incomplete data.

Ethical approval for the study was obtained from the Khartoum Hospital Ethical Board.

\section{Statistics}

Data were analyzed using SPSS version 20 for Windows (SPSS Inc., Chicago, IL, USA). Mean (SD) and proportions of the variables were compared using the Student's t-test and $\chi^{2}$ test, respectively. A P value $<0.05$ was considered significant. Logistic regression analysis was used to assess the factors associated with preeclampsia as the dependent factor, and age, parity, RDW, platelets, and WBC count as independent factors.

\section{Results}

A total of 130 women (65 in each arm) were enrolled in the study. The two groups were well matched in their basic characteristics, with no significant differences in mean age, parity, and BMI. There were also no differences in mean hemoglobin concentration, platelet count, and white cell count between the case and control groups (Table 1).

There were no differences in age, parity, BMI, hemoglobin concentration, platelet count, and white blood cells between women with mild preeclampsia and those with severe. However, the platelet count was significantly lower in women with severe preeclampsia than in those with mild preeclampsia $(\mathrm{P}<0.001$, Table 2$)$.

There was no difference in the mean (SD) RDW between women with preeclampsia and controls $14.5 \pm 1.8 \%$ vs. $14.4 \pm 1.4 \%, \mathrm{P}=0.710$, Figure 1 ). There was no difference in the mean RDW between women with mild and severe preeclampsia $14.7 \pm 1.9 \%$ vs. $13.9 \pm 1.4 \%, \mathrm{P}=0.144$, Figure 2 ).

In logistic regression, there was no association between RDW and preeclampsia (odds ratio $=0.9$, confidence interval $=0.7-1.1, \mathrm{P}=0.952$, Table 3 ). There was no correlation between RDW and systolic blood pressure, Figure 3.

\section{Discussion}

The current study showed no difference in RDW between women with preeclampsia and controls. There was also no difference in RDW between women with mild and severe preeclampsia. In addition, in the current study, there was no correlation between RDW and preeclampsia.

Recently, Keskin and colleagues observed that RDW was significantly higher in the women with preeclampsia and

Table 3 Factors associated with preeclampsia using univariate and multivariate analyses

\begin{tabular}{lll}
\hline Variable & $\begin{array}{l}\text { Univariate } \\
\text { analyses } \\
\text { OR 95\% CI P }\end{array}$ & $\begin{array}{l}\text { Multivariate } \\
\text { analyses } \\
\text { OR 95\% CI P }\end{array}$ \\
\hline Age & $0.90 .9-1.00 .601$ & $0.90 .9-1.00 .468$ \\
parity & $0.90 .8-1.10 .881$ & $1.00 .8-1.20 .959$ \\
Platelets & $1.00 .9-1.00 .905$ & $1.00 .9-1.00 .938$ \\
Red cell distribution width & $0.90 .7-1.20 .961$ & $0.90 .7-1.10 .952$ \\
White blood cells & $1.00 .9-1.20 .942$ & $1.00 .9-1.20 .262$ \\
\hline
\end{tabular}

$\mathrm{OR}=$ Odds ratio, $\mathrm{Cl}=$ confidence interval. 


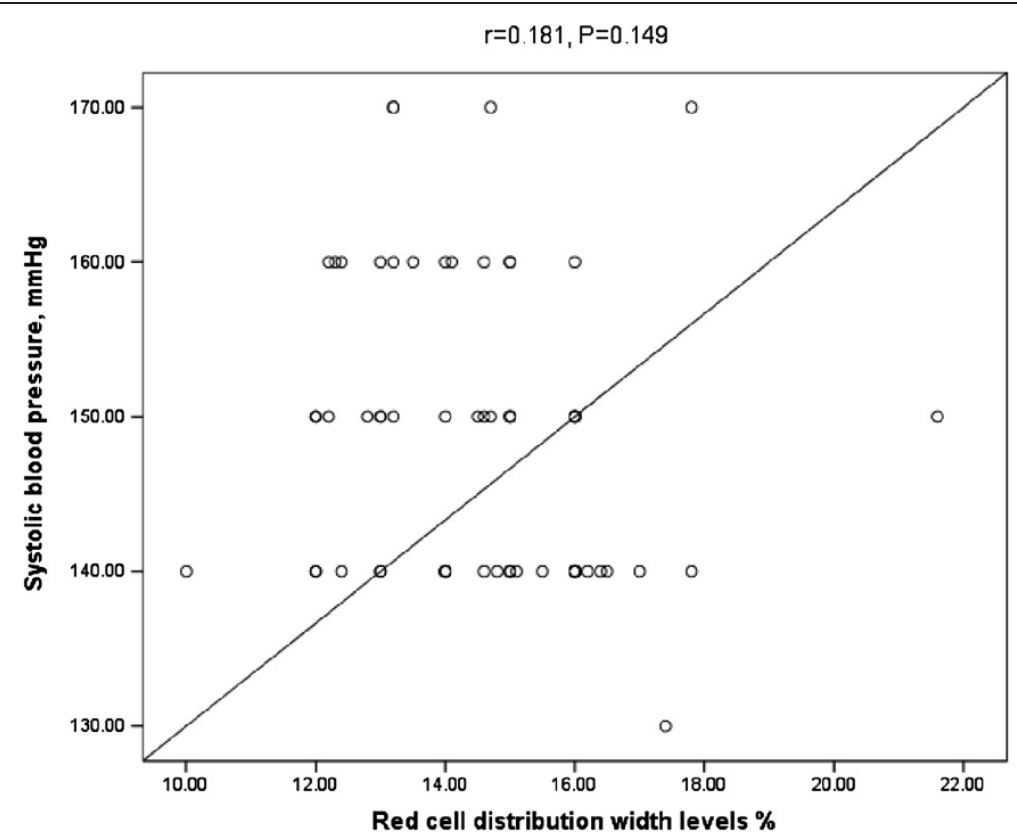

Figure 3 Correlation between RDW and systolic blood pressure.

RDW was associated with the severity of preeclampsia [9]. There are few data on the influence of normal pregnancy on RDW, but a high RDW between 34 weeks of gestation and the onset of labor has been reported [20]. RDW has been recently observed to be associated with hypertension and it is an indicator of poor prognosis in acute myocardial infarction and heart failure [6,21-23]. Although the mechanism of the relationship between RDW and hypertension is not clearly understood, increased inflammation is the most plausible theory [24]. Interestingly, the above mentioned increased inflammation theory of RDW and hypertension has recently been supported by a positive correlation between $C$ reactive protein and RDW levels in preeclamptic women [9]. Inflammation might increase RDW levels via impairment of iron metabolism and disruption of the response to erythropoietin. This could cause immature erythrocytes to enter the circulation by impairing erythrocyte maturation $[25,26]$.

Recently, a variety of studies have supported that RDW might be a useful parameter for gathering useful information, either diagnostic or prognostic, in different diseases [6-8]. However, it is still unclear whether anisocytosis (reflected by RDW) might be the cause, or a simple epiphenomenon of an underlying disease, or perhaps an element of both. Nevertheless, RDW is an easy, inexpensive, routinely reported investigation, which might allow the acquisition of significant diagnostic and prognostic information in patients with hypertension and preeclampsia.

The limitations of the current study are that iron, vitamins (including folic acid), and trace elements were not investigated. We have previously shown a high level of deficiency in these elements among pregnant Sudanese women [13,27], and their deficiency might be responsible for preeclampsia or RDW. Furthermore the previous finding of ascoaition between severe anemia and preeclampsia might need further investigation [11].

\section{Conclusion}

In this study we show that RDW levels are not associated with the presence or severity of preeclampsia.

\section{Competing interests}

The authors declare that they have no competing interests.

\section{Authors' contributions}

HA and IA designed the study. DAR and GIG conducted the clinical part of the study. AMI and GIG participated in the laboratory work. AMI and IA performed statistical analysis. All of the authors approved the final version of the manuscript.

Received: 5 December 2013 Accepted: 18 December 2013 Published: 5 February 2014

\section{References}

1. Duley $L$ : The global impact of pre-eclampsia and eclampsia. Semin Perinatol 2009, 33:30-37.

2. Wang A, Rana S, Karumanchi S: A: preeclampsia: the role of angiogenic factors in its patho- genesis. Physiology (Bethesda) 2009, 24:147-158.

3. Troeger C, Holzgreve W, Ladewig A, Zhong XY, Hahn S: Examination of maternal plasma erythropoietin and activin A concentrations with regard to circulatory erythroblast levels in normal and preeclamptic pregnancies. Fetal Diagn Ther 2006, 21:156-160.

4. Aulakh R, Sohi I, Singh T, Kakkar N: Red cell distribution width [RDW] in the diagnosis of iron deficiency with microcytic Hypochromic Anemia. Indian J Pediatr 2009, 76:265-267.

5. Sultana GS, Haque SA, Sultana T, Rahman Q, Ahmed ANN: Role of red cell distribution width [RDW] in the detection of iron deficiency anemia in pregnancy within the first 20 weeks of gestation. Bangladesh Med Res Counc Bull 2011, 37:102-105. 
6. Tanindi A, Topal FE, Topal F, Celik B: Red cell distribution width in patients with prehypertension and hypertension. Blood Press 2012, 21:177-181.

7. Montagnana M, Cervellin G, Meschi T, Lippi G: The role of red blood cell distribution width in cardiovascular and thrombotic disorders. Clin Chem Lab Med 2011, 50:635-641.

8. Liu DS, Jin Y, Ma SG, Bai F, Xu W: The ratio of red cell distribution width to mean corpuscular volume in patients with diabetic ketoacidosis. Clin Lab 2013, 59:1099-1104.

9. Keskin Kurt R, Aras Z, Silfeler DB, Kunt C, Islimye M, Kosar O, Preeclampsia S o: Relationship of red cell distribution width with the presence and severity of preeclampsia. Clin Appl Thromb Hemost published online 2013. in press.

10. Bueno AA, Ghebremeskel K, Bakheit KH, Elbashir MI, Adam I: Dimethyl acetals, an indirect marker of the endogenous antioxidant plasmalogen level, are reduced in blood lipids of Sudanese pre-eclamptic subjects whose background diet is high in carbohydrate. J Obstet Gynaecol 2012, 32:241-246.

11. Ali AA, Rayis DA, Abdallah TM, Elbashir Ml, Adam I: Severe anaemia is associated with a higher risk for preeclampsia and poor perinatal outcomes in Kassala hospital, eastern Sudan. BMC Res Notes 2011, 26:4-311.

12. Bakheit KH, Bayoumi NK, Eltom AM, Elbashir MI, Adam I: Cytokines profiles in Sudanese women with preeclampsia. Hypertens Pregnancy 2009, 28:224-9.

13. Bakheit KH, Ghebremeskel K, Zaiger G, Elbashir MI, Adam I: Erythrocyte antioxidant enzymes and plasma antioxidant vitamins in Sudanese women with pre-eclampsia. J Obstet Gynaecol 2010, 30:147-50.

14. Abdelrahman EG, Gasim GI, Musa IR, Elbashir LM, Adam I: Red blood cell distribution width and iron deficiency anemia among pregnant Sudanese women. Diagn Pathol 2012, 7:168

15. Ali AA, Adam I: Lack of antenatal care, education, and high maternal mortality in Kassala hospital, eastern Sudan during 2005-2009. J Matern Fetal Neonatal Med 2011, 24:1077-1078.

16. Ali AA, Okud A, Khojali A, Adam I: High incidence of obstetric complications in Kassala hospital, eastern Sudan. J Obstet Gynaecol 2012, 32:148-149.

17. ACOG practice bulletin: Diagnosis and management of preeclampsia and eclampsia. Obstet Gynecol 2002, 99:159-167.

18. Sysmex KX-21 N Operator's Manual: Sysmex Corporation. 2006. http://www. blockscientificstore.com/Sysmex-KX-21N-Hematology-Analyzer-p/sysmexkx-21.htm

19. Adam I, Ahmed S, Mahmoud MH, Yassin MI: Comparison of HemoCue ${ }^{\oplus}$ hemoglobin-meter and automated hematology analyzer in measurement of hemoglobin levels in pregnant women at Khartoum hospital, Sudan. Diagn Pathol 2012, 21:7-30

20. Shehata HA, Ali MM, Evans-Jones JC, Upton GJ, Manyonda IT: Red cell distribution width [RDW] changes in pregnancy. Int I Gynaecol Obstet 1998, 62:43-6.

21. Al-Najjar Y, Goode KM, Zhang J, Cleland JG, Clark AL: Red cell distribution width: an inexpensive and powerful prognostic marker in heart failure. Eur J Heart Fail 2009, 11:1155-1162.

22. Patel KV, Ferrucci L, Ershler WB, Longo DL, Guralnik JM: Red blood cell distribution width and the risk of death in middle-aged and older adults. Arch Intern Med 2009, 169:515-523.

23. Isik T, Kurt M, Ayhan E, Tanboga IH, Ergelen M, Uyarel H: The impact of admission red cell distribution width on the development of poor myocardial perfusion after primary percutaneous intervention. Atherosclerosis 2012, 224:143-149.

24. Ozcan F, Turak O, Durak A, Işleyen A, Uçar F, Giniş Z, Uçar F, Başar FN, Aydoğdu S: Red cell distribution width and inflammation in patients with non-dipper hypertension. Blood Press 2013, 22:80-85.

25. Pierce CN, Larson DF: Inflammatory cytokine inhibition of erythropoiesis in patients implanted with a mechanical circulatory assist device. Perfusion 2005, 20:83-90.

26. Weiss G, Goodnough LT: Anemia of chronic disease. N Engl J Med 2005, 352:1011-1023.

27. Abdelrahim II, Mahgoub HM, Mohamed AA, Ali NI, Elbashir Ml, Adam : Anaemia, folate, zinc and copper deficiencies among adolescent schoolgirls in eastern Sudan. Biol Trace Elem Res 2009, 132:60-66.

doi:10.1186/1746-1596-9-29

Cite this article as: Abdullahi et al: Red blood cell distribution width is not correlated with preeclampsia among pregnant Sudanese women. Diagnostic Pathology 2014 9:29.

\section{Submit your next manuscript to BioMed Central and take full advantage of:}

- Convenient online submission

- Thorough peer review

- No space constraints or color figure charges

- Immediate publication on acceptance

- Inclusion in PubMed, CAS, Scopus and Google Scholar

- Research which is freely available for redistribution 